\title{
Pengembangan Modul Praktikum SPSS Versi 20 pada Matakuliah Statistika dan Probabilitas Berbasis Web untuk Memfasilitasi Keterampilan Pengujian Hipotesis Penelitian
}

\author{
Ratna Widyastuti ${ }^{1}$, Ellya Nurfarida ${ }^{2}$ \\ Politeknik Kediri \\ 1nana89widya@gmail.com, ${ }^{2}$ ellya.nurfarida@gmail.com
}

\begin{abstract}
ABSTRAK. Media pembelajaran menjadi suatu elemen utama proses pembelajaran aktif. Salah satu matakuliah program studi D3 Teknik informatika adalah matakuliah statistik dan probabilitas. Konsep statistika terdiri dari statistika deskriptif dan statistika inferensial. Statistika deskriptif berfokus pada deskripsi data dan ststistika inferensial berfokus pada pengujian data statistik. Penelitian ini merupakan penelitian pengembangan yang menghasilkan media pembelajaran berupa modul praktikum SPSS versi 20 berbasis web. Tahap-tahap pengembangan pada penelitian ini mengacu dari Plomp yang meliputi(1)preliminary research, (2)prototyping phase, dan (3) assessment phase.Berdasarkan hasil penelitian, dapat disimpulkan : (1) Modul praktikum SPSS versi 20 berbasis web dapat diakses di alamat http://sinau-barengstatistika.000webhostapp.com, (2) Modul praktikum SPSS versi 20 berbasis web yang dibuat memenuhi kriteria valid ditunjukkan dari hasil angket validitassebesar $85,42 \%$;(3) Respon mahasiswa terhadap implementasi modul praktikum SPSS versi 20 berbasis web termasuk kriteria sangat baik ditunjukkan dari hasil angket respon menunjukkan hasil sebesar 3,85.

Kata Kunci: JITIKA; web, pengembangan Modul, SPSS versi 20
\end{abstract}

\begin{abstract}
Learning media is a major element of the active learning process. One of the subjects in the D3 study program in Informatics Engineering is statistics and probability. Statistics is a subject that studies descriptive statistics and inferential statistics. Descriptive statistics focus on the description of data and inferential statistics focusing on testing statistical data. This research is a development research that produces learning media in the form of web-based SPSS version 20 practicum modules. The development stages in this study refer to Plomp which includes (1) preliminary research, (2) prototyping phase, and (3) assessment phase. Based on the results of the study, it can be concluded: (1) Web-based SPSS version 20 practicum module can be accessed at the address http://sinau-bareng-statistika.000webhostapp.com, (2) The web-based SPSS version 20 practicum module meets valid criteria indicated by the results of the questionnaire validity of $85.42 \%$; (3) Student responses to the implementation of web-based SPSS version 20 practicum modules including very good criteria shown from the results of the response questionnaire showed results of 3.85 .
\end{abstract}

Keywords: JITIKA; web, module development, SPSS version 20

\section{PENDAHULUAN}

Arus komunikasi dan informasi baik cetak maupun elektronik selain mempunyai peran yang sangat srategis bagi keberhasilan pembangunan sistem politik dan demorasi, juga berperan dalam upaya mencerdaskan kehidupan bangsa salah satu sumber pembelajaran yang dituju oleh mahasiswa adalah internet. Dengan mudah internet menyajikan semua sumber belajar hanya dengan memesan apa yang diinginkan melalui situs pencarian popular yaitu google. Media Belajar menjadi suatu elemen utama proses pembelajaran aktif. Pembelajaran aktif menekankan pada aktivitas pebelajar dalam mengakses berbagai informasi dari berbagai sumber, untuk dibahas dalam proses pembelajaran dalam kelas, sehingga memperoleh berbagai pengalaman yang tidak saja menambah pengetahuan, tapi juga kemampuan analisis dan sintesis. Mahasiswa dituntut berperan lebih aktif dalam mengembangkan cara-cara belajar mandiri, mulai dari perencanaan, pelaksanaan dan penilaian proses belajar.

Pembelajaran di abad 21 ditandai dengan peningkatan penggunaan berbagai teknologi pada pembelajaran. Mahasiswa teknik informatika tidak asing lagi dengan pembelajaran yang melibatkan teknologi salah satunya komputer. Mahasiswa dituntut memiliki inisiatif, kritis, kreatif dan cakap memecahkan masalah. Hubungan mahasiswa dengan komputer menjadi interaksi komunikatif yang menuntut kecakapan berfikir tingkat tinggi. Penggunaan media pembelajaran yang tepat menjadi suatu langkah strategis meningkatkan standar pendidikan nasional, khususnya standar proses, sarana dan prasarana. (Rusman, 2017)mengatakan pembelajaran merupakan akumulasi dari konsep mengajar (teaching) dan konsep belajar (learning) yang ditekankan pada aktivitas siswa. Oleh karena itu dalam sistem pembelajaran terdapat komponen peserta didik, tujuan, materi untuk mencapai tujuan, fasilitas 
dan prosedur serta media yang harus dikembangkan. Pembelajaran yang dirancang dengan memfaslitasi mahasiswa belajar mandiri dapat melatih mereka menjadi pebelajar mandiri sepanjang hayat, dan pada gilirannya mereka menjadi komponen penting untuk mewujudkan masyarakat belajar.

(Sadiman, Raharjo, \& dkk, 2006)menyebutkan media pembelajaran ditinjau dari kesiapan pengadaannya dikelompokkan menjadi dua yaitu media yang sudah merupakan komoditi perdagangan dan terdapat di pasaran luas dalam keadaan siap pakai (media by utilization), dan media rancangan karena perlu dirancang dan dipersiapkan secara khusus untuk maksud atau tujuan pembelajaran tertentu (media by design). Modul praktikum termasuk salah satu media pembelajaran buatan yang dirancang dengan tujuan agar mahasiswa dapat melaksanakan pratikum secara mandiri. Dalam penelitian ini praktikum yang dipilih adalah praktikum pengujian hipotesis pada matakuliah statistika dan probabilitas.

Modul sebagai salah satu bahan ajar mempunyai salah satu karakteristik adalah prinsip belajar mandiri. (Anwar, 2010)menyatakan bahwa karakteristik modul pembelajaran sebagai berikut: (1) Self instructional maksudnya mahasiswa mampu membelajarkan diri sendiri, tidak tergantung pada pihak lain; (2) Self contained maksudnya meluruh materi pembelajaran dari satu unit kompetensi yang dipelajari terdapat didalam satu modul utuh; (3) Stand alone maksudnya modul yang dikembangkan tidak tergantung pada media lain atau tidak harus digunakan bersama-sama dengan media lain; (4) Adaptif maksudnya modul hendaknya memiliki daya adaptif yang tinggi terhadap perkembangan ilmu dan teknologi; dan yang terakhir (5) User friendly maksudnya modul hendaknya juga memenuhi kaidah nyaman dengan pemakainya.

Belajar menggunakan modul memiliki banyak manfaat, mahasiswa dapat bertanggung jawab terhadapkegiatan belajarnya sendiri, pembelajaran dengan modul sangat menghargai perbedaan individu, sehingga siswa dapat belajar sesuai dengan tingkat kemampuannya, maka pembelajaran semakin efektif dan efisien. (Lasmiyati \& Harta, 2014)menjelaskan kelebihan pembelajaran dengan modul yaitu (a) modul dapat memberikan umpan balik sehingga pebelajar mengetahui kekurangan mereka dan segera melakukan perbaikan, (b) dalam modul ditetapkan tujuan pembelajaran yang jelas sehingga kinerja siswa belajar terarah dalam mencapai tujuan pembelajaran, (c) modul yang didesain menarik, mudah untuk dipelajari, dan dapat menjawab kebutuhan tentu akan menimbulkan motivasi siswa untuk belajar, (d) modul bersifat fleksibel karena materi modul dapat dipelajari oleh siswa dengan cara dan kecepatan yang berbeda, (e) kerjasama dapat terjalin karena dengan modul persaingan dapat diminimalisir dan antara pebelajar dan pembelajar, dan (f) remidi dapat dilakukan karena modul memberikan kesempatan yang cukup bagi siswa untuk dapat menemukan sendiri kelemahannya berdasarkan evaluasi yang diberikan.

(Tirta, 2014)menjelaskan media berbasis web memiliki beberapa keunggulan antara lain bisa diakses dengan lebih fleksibel, control dan lulusan yang lebih spontan. Pemanfaatan media yang dilengkapi dengan lembar tugas membuat mahasiswa tetap menjadi pebelajar aktif dan kritis. Pengembangan media berbasis web yang dirancang dengan baik berpotensi menjadi lab virtual sebagai pusat belajar statistika yang bermakna dan menarik. Penelitian lain oleh (Barokati \& Annas, 2013 )tentang pengembangan pembelajaran yang menggabungkan antara e-learning dengan komposisi (50\%) menggunakan media online yaitu web dan media offline yaitu presentasi power point, tatap muka serta buku panduan sebagai petunjuk penggunaan memberikan kontribusi pada pengembangan pembelajaran dan direspon positif oleh mahasiswa.

Salah satu matakuliah pada kurikulum program studi D3 Teknik informatika adalah matakuliah statistik dan probabilitas. Mendengar kata statistik seperti momok yang harus dipelajari. Statistika merupakan matakuliah yang mempelajari tetang statistika deskriptif dan statistika inferensial. Statistika deskriptif berfokus pada deskripsi data dan ststistika inferensial berfokus pada pengujian data statistik.Matakuliah statistika dan Probabilitas merupakan matakuliah yang ditempuh mahasiswa disemester 5 (lima). Statistika Probabilitas terdiri dari 3 sks dengan rincian 1 sks teori dan 2 sks praktikum sehingga jam tempuhnya menjadi 5 jam perkuliahan dalam satu minggu. Capaian Pembelajaran yang diharapkan pada matakuliah statistika dan probabilitas adalah "Setelah mengikuti matakuliah statistika dan peluang diharapkan mahasiswa mampu mengolah dan menganalisis data statistik serta terampil mengadakan pengujian hipotesis menggunakan metode pengujian yang valid 
sesuai dengan karakteristik sampel penelitian".Berdasarkan latar belakang tersebut, peneliti mengadakan penelitian tentang pengembangan modul praktikum pengujian hipotesis menggunakan SPSS 20 pada matakuliah statistika dan probabilitas untuk mencapai tujuan pembelajaran yang direncanakan yaitu terampil mengadakan pengujian hipotesis menggunakan metode pengujian yang valid sesuai dengan karakteristik sampel penelitian.

\section{METODE}

Model Pengembangan

Penelitian initermasuk jenis penelitian pengembangan. Produk yang dikembangkanadalah modul praktikum SPSS 20 pada matakuliah statistika dan probabilitas berbasis web untuk memfasilitasi keterampilan pengujian hipotesis penelitian kuantitatif. Pemilihan model pengembanganini karenamemiliki urutan kegiatanyangsistematis, sederhanadan jelas sehingga mudah dipahamidan diterapkan dalam melakukanpengembangan.Tahap-tahap pengembangan mengacu dariPlomp (2010: 15) yang meliputi(1)preliminary research(penelitian awal), (2)prototyping phase (tahap pengembangan), dan (3) assessment phase (tahappenilaian).

Prosedur Penelitian Pengembangan

Prosedur pengembangan modul yang akan dilakukan adalah sebagai berikut.

1. Preliminary Research(Penelitian Awal)

Pada tahap Preliminary Research, informasi dikumpulkan dengan melakukan prasurvei yang bertujuan untuk menelaah kurikulum matematika SMP, menelaah karakteristik mahasiswa prodi Teknik Informatika berdasarkan kemampuan, latar belakang pengetahuan, perkembangan kognitif dan mengetahui pembelajaran yang berlangsung juga mengumpulkan informasi yang berkaitan dengan bahan ajar yang digunakan dosen dan mahasiswa apakah masih layak digunakan dan kontekstual. Setelah mengetahui hal-hal tersebut selanjutnya kegiatan yang dilakukan antara lain:

a. Menganalisis kebutuhan untuk melakukan perbaikan proses pembelajaran dan;

b. Memilih materi dan menentukan perancangan modul yang akan digunakan.

2. Prototyping phase (tahap pengembangan berbasis web)

Langkah selanjutnya adalah pengembangan yang mencakup kegiatan memilih cakupan materi, menentukan sasaran dari produk, perumusan alat pengukuran keberhasilan dan beberapa hal lainnya yang terkait dengan persiapan pengembangan produk. Selanjutnya melakukan desain produk, produk yang dikembangkan adalah modul praktikum SPSS versi 20 berbasis web.

Kebutuhan Fungsional

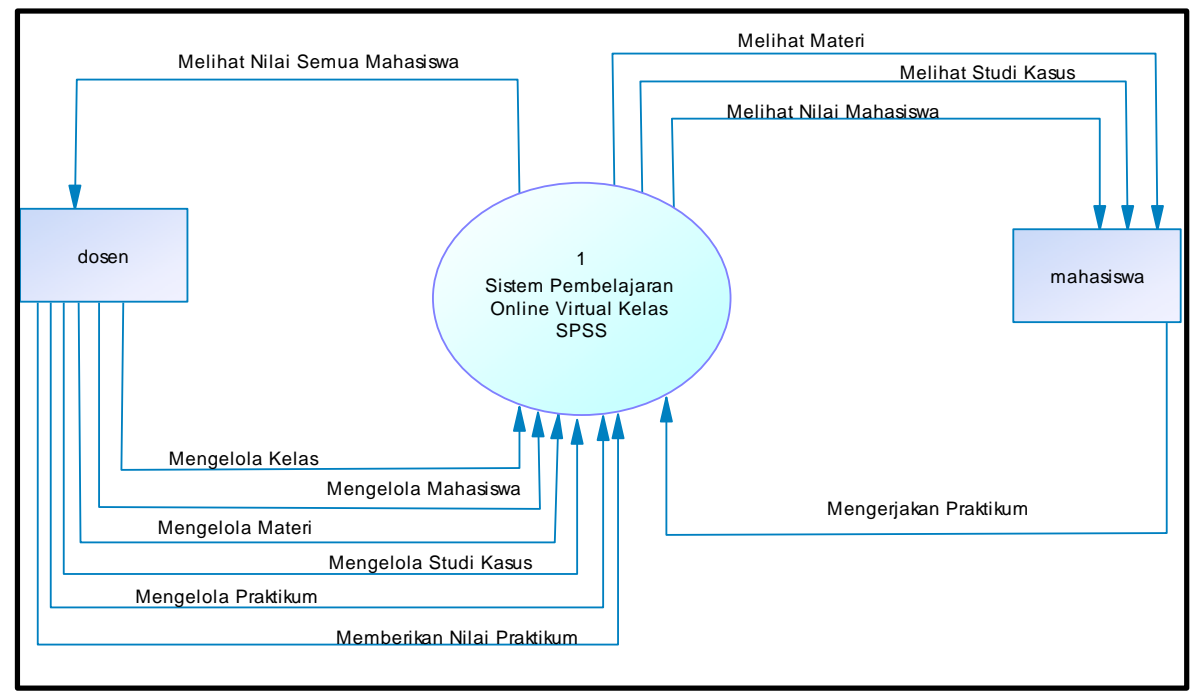

Gambar 1. DFD Level 0 Sistem Pembelajaran Online Virtual Kelas SPSS

Seperti ditunjukkan Gambar. 1 modul berbasis web dapat digunakan oleh dosen dan mahasiswa. Dosen dapat mengelola data kelas media, data mahasiswa, data materi, data studi kasus, data 
praktikum, memberikan nilai praktikum, dan melihat nilai mahasiswa. Sedangkan mahasiswa dapat mengerjakan praktikum, melihat materi, melihat studi kasus, dan melihat nilai.

Alur sistem

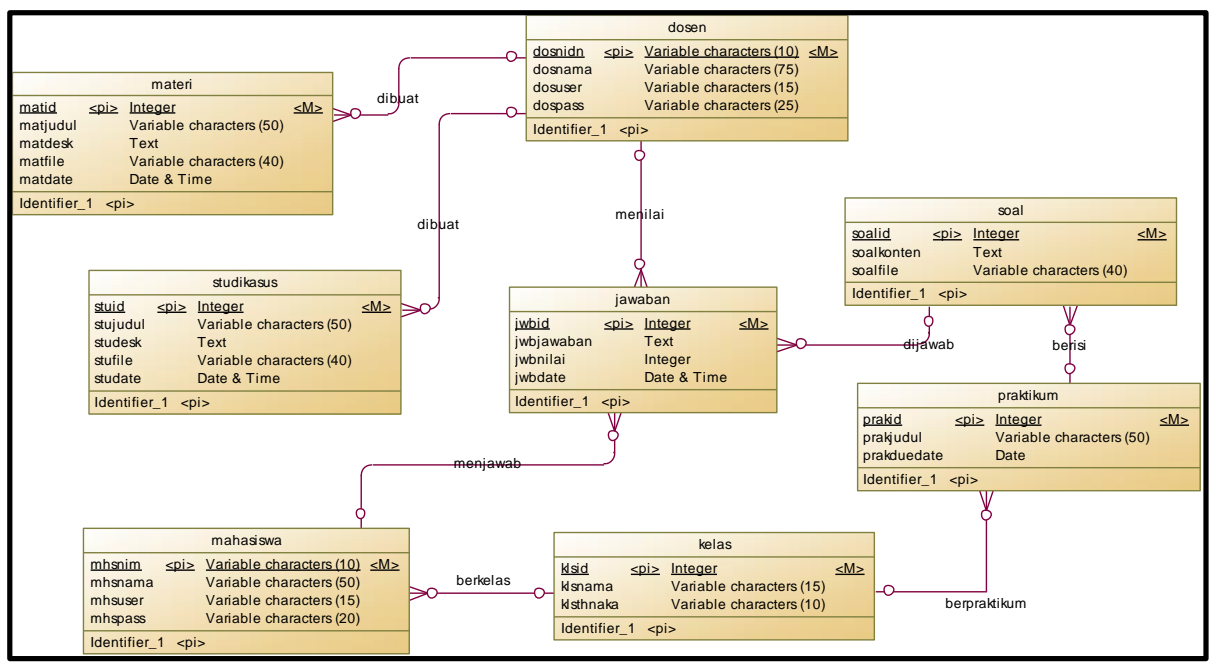

Gambar 2. ERD Sistem Pembelajaran Online Virtual Kelas SPSS

Entity Relationship Diagram (ERD) seperti ditunjukkan Gambar 2. terdapat delapan tabel. Tabel tersebut antara lain tabel dosen, materi, studi kasus, jawaban, soal, praktikum, mahasiswa, dan kelas. Materi dan studi kasus dibuat oleh dosen. Dosen dapat menilai jawaban dari mahasiswa. Soal berisi praktikum dijawab mahasiswa. Dari masing-masing tabel memiliki beberapa atribut dan id sebagai primary key.

\section{1) Assessment phase (tahap penilaian)}

Penilaian produk terdiri atas penilaian kevalidan, kepraktisan, dan keefektifan modul praktikum. Pada fase ini dilakukan dua aktivitas, yaitu (a) validasi produk untuk menilai kevalidan, (b) uji coba produk yang meliputi uji coba kelompok dan uji coba pada situasi nyata di lapangan untuk menilai kepraktisan dan keefektifan modul praktikum. Untuk menilai kevalidan, aktivitas yang dilakukan adalah sebagai berikut.

a. Meminta penilaian validator Ahli tentang kevalidan modul praktikum dan instrumen yang telah dibuat. Penilaian ini menggunakan lembar validasi;

b. melakukan analisis terhadap hasil validasi untuk menentukan tindakan selanjutnya; kesimpulan analisis validasi selanjutnya disesuaikan dengan kriteria pada Tabel 1 berikut.

Tabel 1. Kriteria Validitas Media

\begin{tabular}{cc}
\hline Kriteria & Keterangan \\
\hline $75 \% \leq S V \leq 100 \%$ & Valid tanpa revisi \\
\hline $50 \% \leq S V<75 \%$ & Belum valid dengan sedikit revisi \\
\hline $25 \% \leq S V<50 \%$ & Belum valid dengan banyak revisi \\
\hline $0 \% \leq S V<25 \%$ & Tidak valid \\
\hline
\end{tabular}

c. jika hasil analisis menunjukkan valid tanpa revisi, maka akan dilanjutnya dengan uji coba kelompok.

d. jika hasil analisis menunjukkan valid dengan revisi kecil, maka akan dilakukan revisi terlebih dahulu dan selanjutnya dilakukan uji coba di kelompok. 
e. jika hasil analisis menunjukkan tidak valid, maka dilakukan revisi besar sehingga diperoleh perangkat baru, kemudian meminta penilaian ahli lagi. Di sini ada kemungkinan terjadi siklus (kegiatan validasi secara berulang) untuk memperoleh perangkat yang valid.

Uji coba produk dimaksudkan untuk mengumpulkan data yang dapat digunakan sebagai dasar untuk menyimpulkan respon mahasiswa terhadap modul berbasis web yang dikembangkan. Uji coba dilakukan dengan memberikan produk modul kepada 2 (dua) teman sejawat dan 11 mahasiswayang ditunjuk dengan kemampuan tinggi, sedang dan rendah. Data hasil uji coba dianalisis untuk mengetahui apakah respon mahasiswa baik atau tidak baik. Daftar pertanyaan berupa angket sebagai instrumen pengumpulan data untuk mendapatkan data tentang keterampilan mahasiswa, kelayakan modul praktikum dari segi kelayakan isi, penyajian, bahasa, gambar dan komponen kegrafisan. Penelitian dilakukan pada bulan Mei sampai Desember 2018 di Prodi Teknik Informatika Politeknik Kediri. Kesimpulan angket respon mahasiswa sesuai kriteria pada Tabel 2 berikut:

Tabel 2. Kriteria rata-rata skor respon mahasiswa

\begin{tabular}{cc}
\hline Kriteria & Keterangan \\
\hline $3,51 \leq S M \leq 4,00$ & Respon mahasiswa sangat baik \\
\hline $2,51 \leq S M<3,51$ & Respon mahasiswa baik \\
\hline $1,51 \leq S M<2,51$ & Respon mahasiswa cukup baik \\
\hline $1,00 \leq S M<1,51$ & Respon mahasiswa kurang baik \\
\hline
\end{tabular}

Adaptasi dari (Hobri, 2010)

\section{HASIL DAN PEMBAHASAN}

Setelah tahap identifikasi masalah dan tahap perancangan sistem tahap berikutnya adalah tahap implementasi. Pada tahap mplementasi ini menampilkan hasil gambar dari Kegiatan ini juga merupakan usaha untuk menentukan apakah aplikasi yang dirancang sudah relevan atau belum.

\section{Halaman Login}

Login digunakan untuk membatasi user. User dari modul SPSS tipe 20 berbasis web ini adalah admin dan mahasiswa. Setelah berhasil login terdapat beberapa pilihan menu pada sistem. Halaman login dapat ditunjukkan pada Gambar 3. Pada halaman login terdapat isian username,password, dan button Sign In.

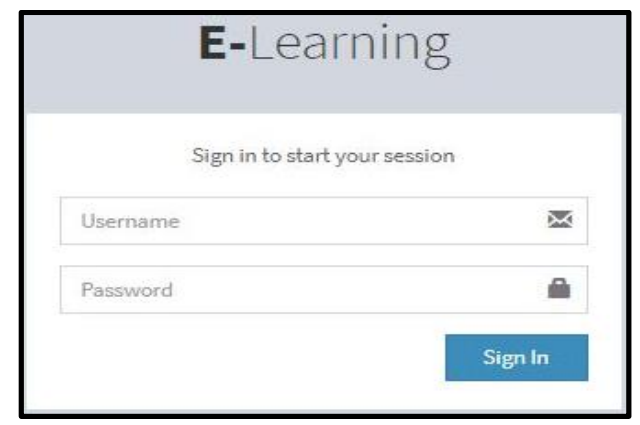

Gambar 3. Halaman Login

\section{Halaman Admin}

Terdapat tampilan jumlah mahasiswa, jumlah materi, jumlah studi kasus, dan jumlah soal pada beranda admin, ditunjukkan Gambar 4.

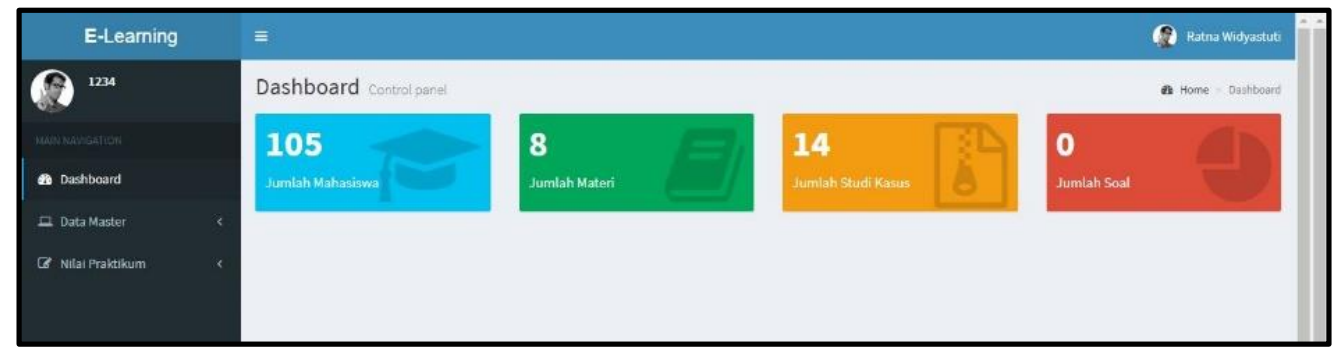

Gambar 4. Halaman Beranda Admin 


\section{Halaman Data Master Dosen}

Halaman Data Master - Dosen, menampilkan data dosen yang telah dimasukkan ke dalam sistem. Data dosen yang ditampilkan adalah NIDN dan nama dosen dengan aksi edit dan hapus, Formulir isian data dosen ditunjukkan pada Gambar 5 terdiri dari NIDN dan nama dosen untuk menambah data dosen. Inputan data tersebut akan disimpan pada tabel dosen. Halaman data master dosen ditunjukkan pada Gambar 6.

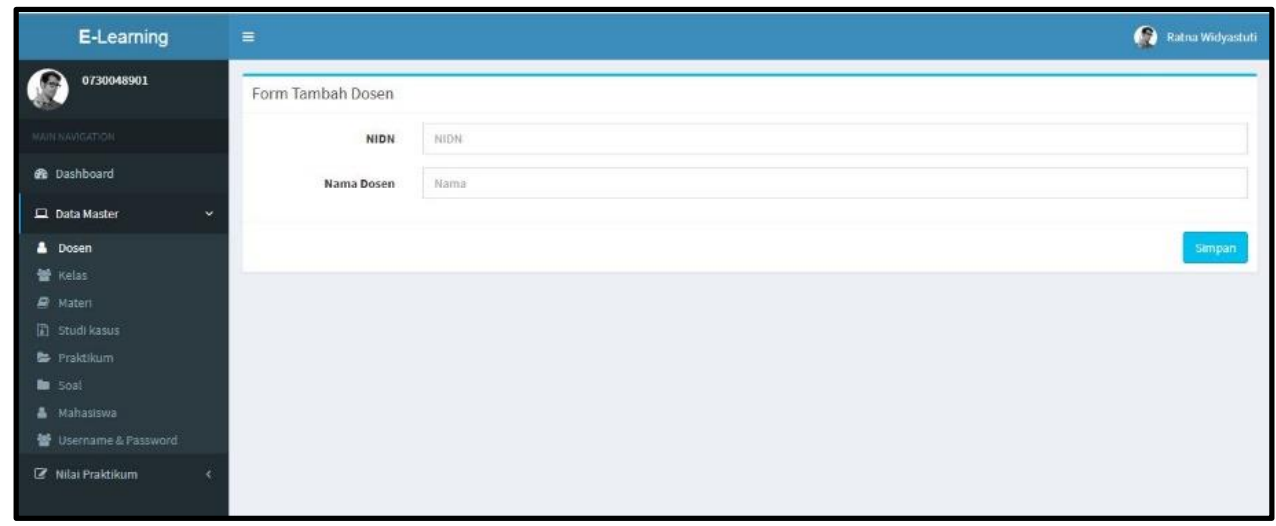

Gambar 5. Halaman Tambah Data Dosen

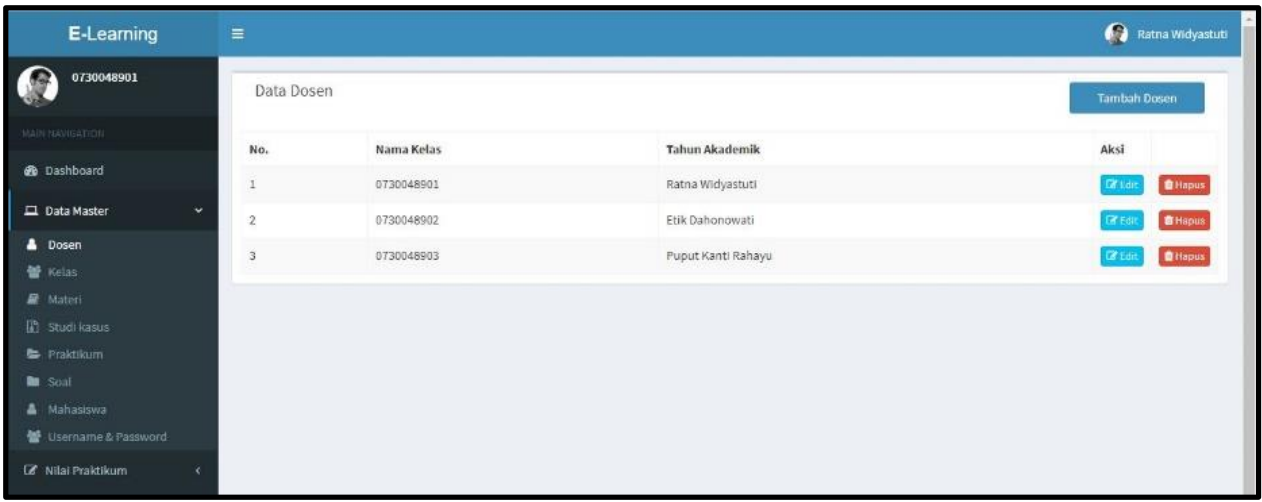

Gambar 6. Halaman Tampil Data Dosen

\section{Halaman Data Master Kelas}

Halaman Data Master-Kelas menampilkan data kelas. Data kelas terdiri dari nama kelas, tahun akademik serta aksi edit dan hapus.Form tambah kelas tersebut terdiri darimasukan nama kelas dan tahun akademik. Button tambah kelas yang terdapat di tampilan data kelas akan mengakses halaman tambah kelas seperti pada Gambar 7. Data kelas yang berhasil dimasukkan akan disimpan pada tabel kelas. Halaman data master kelas ditunjukkan Gambar 8.

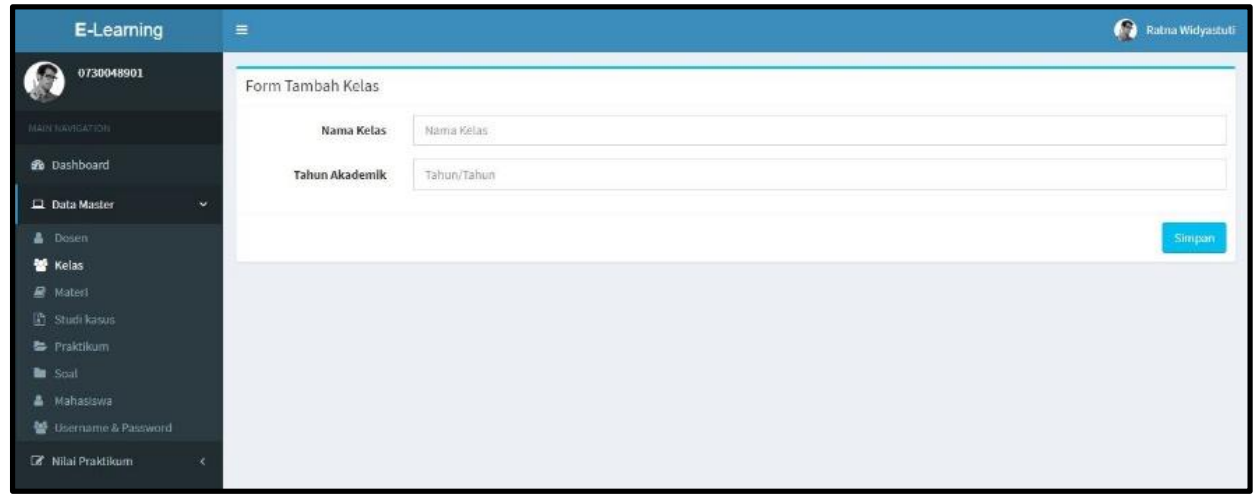

Gambar 7. Halaman Tambah Data Kelas 


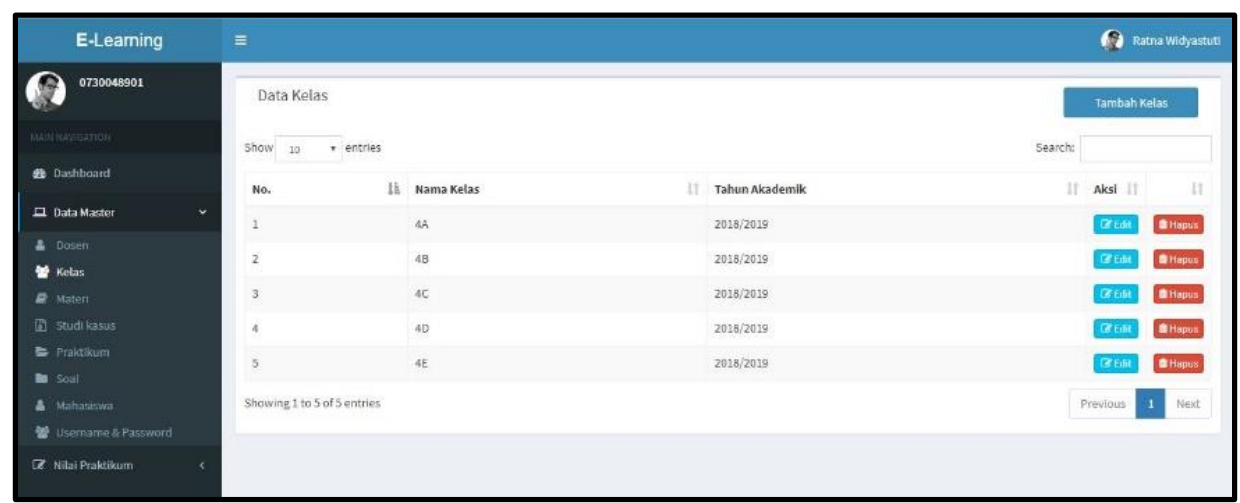

Gambar 8. Halaman Tampil Data Kelas

\section{Halaman Data Master Materi}

Halaman Data MasterMateri menampilkan data materi yaitu judul, tanggal unggah materi, video, daftar file, serta aksi edit dan hapus.Button tambah materi yang terdapat di tampilan data materi akan mengakses ke halaman tambah materi seperti pada Gambar 9. Form tambah materi terdir dari isian judul, deskripsi, dan link video. Data materi yang berhasil diinputkan akan disimpan pada tabel materi ditunjukkan pada Gambar 10.

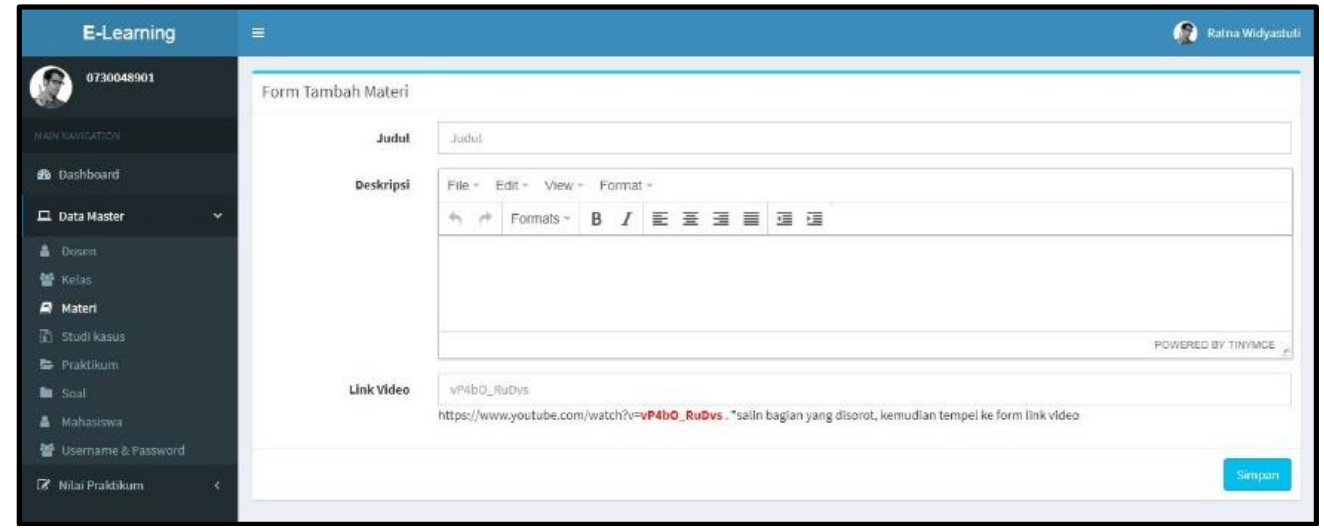

Gambar 9. Halaman Tambah Data Materi

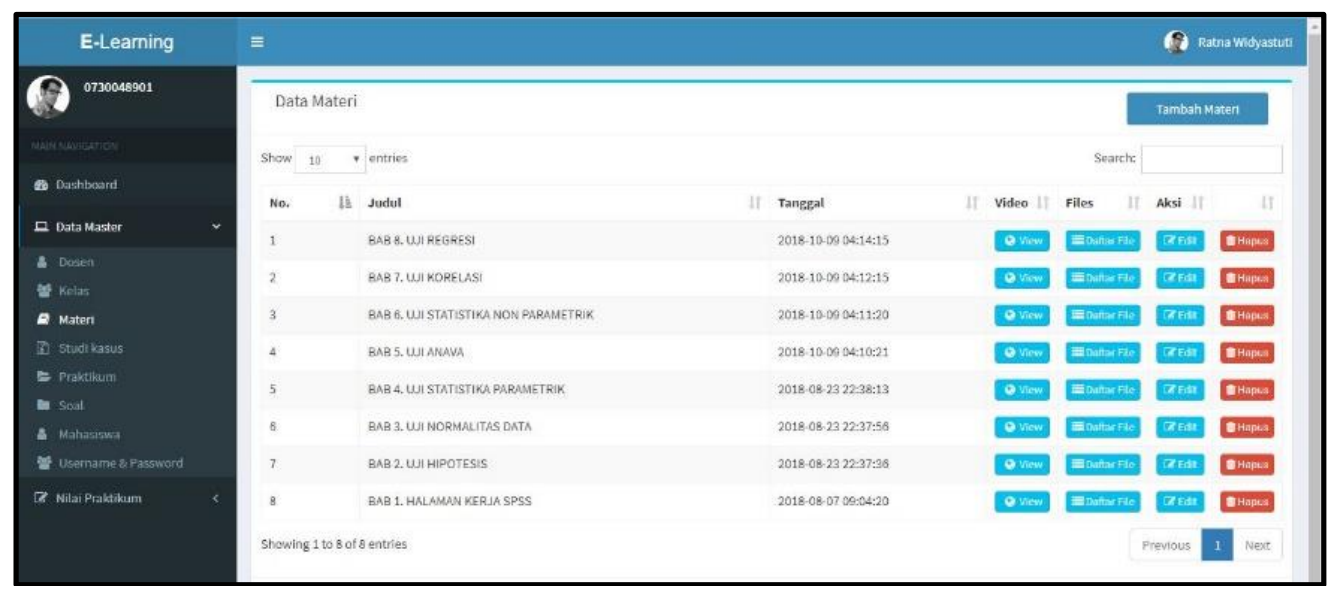

Gambar 10. Halaman Tampil Data Materi

\section{Halaman Data Master Studi Kasus}

Halaman Data MasterStudi Kasus, menampilkan data studi kasus dari setiap materi yang diajarkan. Data studi kasus yang ditampilkan adalah judul, tanggal unggal studi kasus, file yang dapat 
diunduh, serta aksi edit dan hapus.Button tambah studi kasus yang terdapat di tampilan data studi kasus akan mengakses ke halaman tambah studi kasus seperti pada Gambar 11. Form tambah studi kasus terdiri dari isian judul, deskripsi, dan input file untuk menambah data studi kasus. Inputan data tersebut akan disimpan pada tabel studi kasus.Halaman data master studi kasus ditunjukkan Gambar 12.

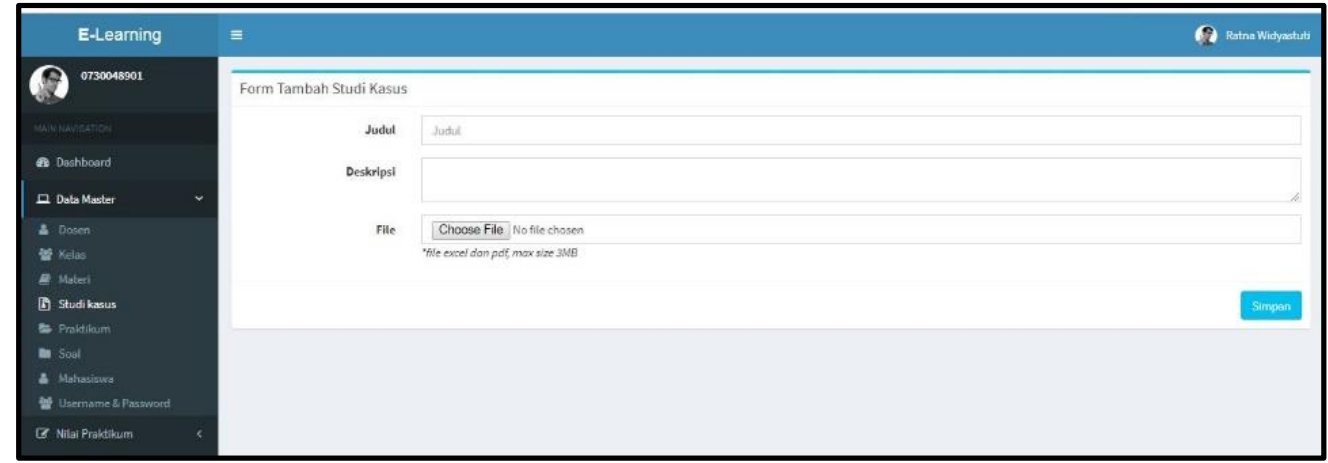

Gambar 11. Halaman Tambah Data Studi Kasus

\begin{tabular}{|c|c|c|c|c|c|}
\hline E-Learning & \multicolumn{3}{|l|}{$\equiv$} & \multicolumn{2}{|r|}{ 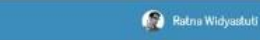 } \\
\hline (2) & \multicolumn{3}{|c|}{ Data Studi Kasus } & \multicolumn{2}{|r|}{ Tambain Sthat Kensis } \\
\hline mention & \multicolumn{2}{|c|}{ Show to vertroes } & & \multirow{2}{*}{ Search } & \\
\hline a Desthoserd & No. & It Juduat & 11. Tanegat & & Aksi If \\
\hline a dota waster & 1 & 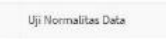 & $2018: 0024$ 13:467:37 & Duniman & 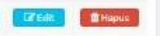 \\
\hline 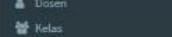 & 2 & Uil Tsous Sompel & 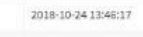 & Dunation & (x) \\
\hline ge natsi & 3 & 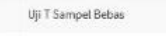 & $2018: 0.2413: 35350$ & Bunatim & 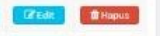 \\
\hline In Sucthows & 4 & Uit $T$ Sompel Berpasangen & 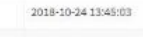 & Dinim & 때 \\
\hline $\begin{array}{l}\text { OProbilum } \\
\text { a soal }\end{array}$ & 5 & Uji Z Sampee Betas & $2018 \cdot 1024135 \cdot 4 \cdot 23$ & Dunatern & 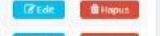 \\
\hline 2 wheseran & 6 & Orevery fanors & 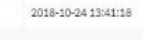 & Dunam & 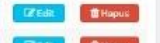 \\
\hline 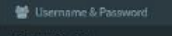 & 7 & Two Way Anowa & $2018: 1022413: 402: 28$ & Dunatim & 1 cores \\
\hline \multirow[t]{4}{*}{ (a) Nal Pratitum } & 8 & vij Chi Custritat & 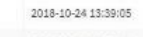 & Dunatien & 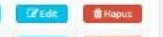 \\
\hline & 9 & 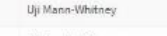 & 2019:-10:2413:3:64:41 & Dunim & 1 एकen \\
\hline & 10 & Uji Korelas Pearion & 2018:-10:24 07:27:26 & Sunate & 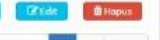 \\
\hline & \multicolumn{3}{|c|}{ 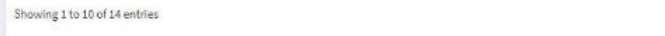 } & & remoun 1 I Ned \\
\hline
\end{tabular}

Gambar 12. Halaman Tampil Data Studi Kasus

\section{Halaman Data Master Soal Praktikum}

Halaman data master soal praktikum terdiri dari judul praktikum, soal praktikum, aksi edit dan aksi hapus. Button tambah soal praktikum yang terdapat di halaman menu Data Master akan mengakses halaman tambah praktikum seperti pada Gambar 13. Form tambah soal praktikum terdapat isian judul yang mengambil data judul dari praktikum, deskripsi, dan unggah file berupa pdf atau word. Datayang berhasil diinputkan akan disimpan pada tabel soal. Halaman data master soal praktikum ditunjukkan pada Gambar 14.

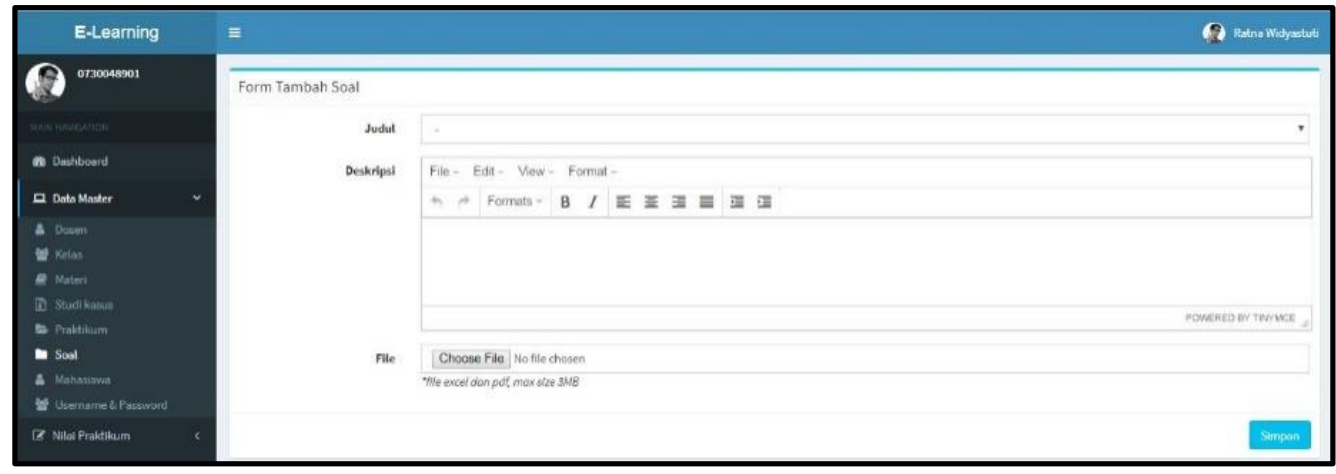

Gambar 13. Halaman Tambah Soal Praktikum 


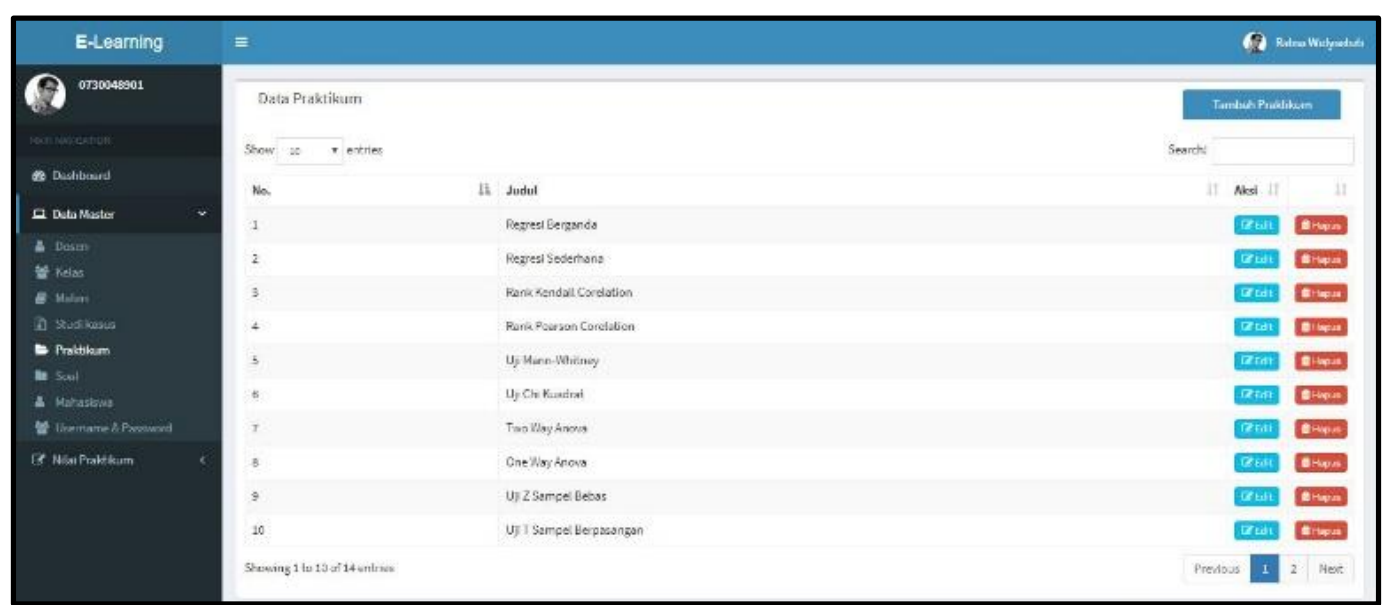

Gambar 14. Halaman Tampil Data Praktikum

\section{Halaman Data Master Mahasiswa}

Halaman data master mahasiswa menampilkan data mahasiswa yaitu NIM, nama, kelas, tahun akademik, serta aksi edit dan hapus. Button tambah mahasiswa akan mengakses tambah data mahasiswa. Form tambah mahasiswa terdapat isian NIM, nama, dan kelas untuk menambah data mahasiswa, seperti ditunjukkan Gambar 15 Inputan data tersebut akan disimpan pada tabel mahasiswa. Halaman Data Master Mahasiswa ditunjukkan Gambar 16.

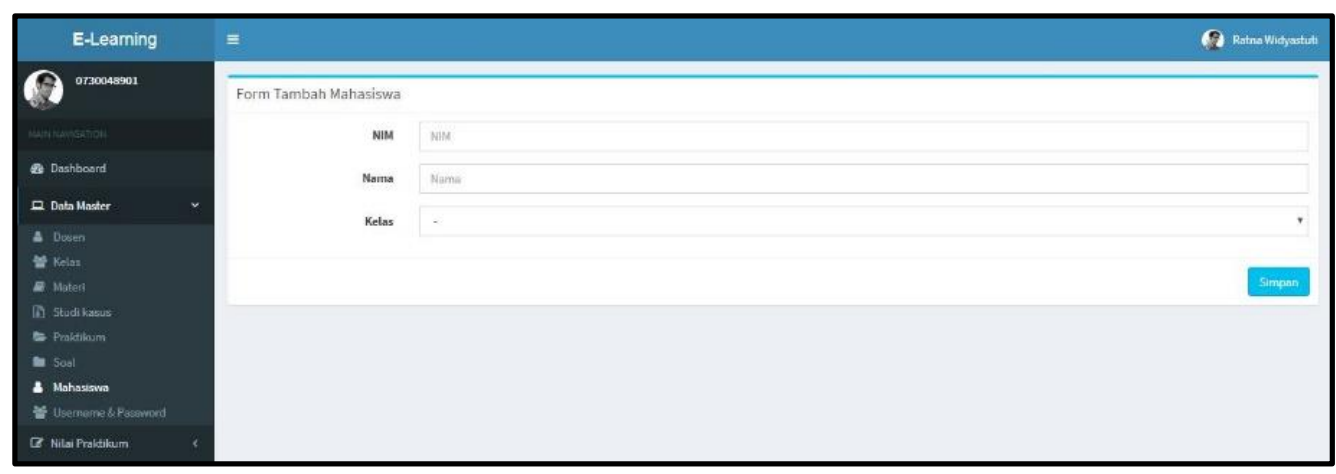

Gambar 15. Halaman Tambah Data Mahasiswa

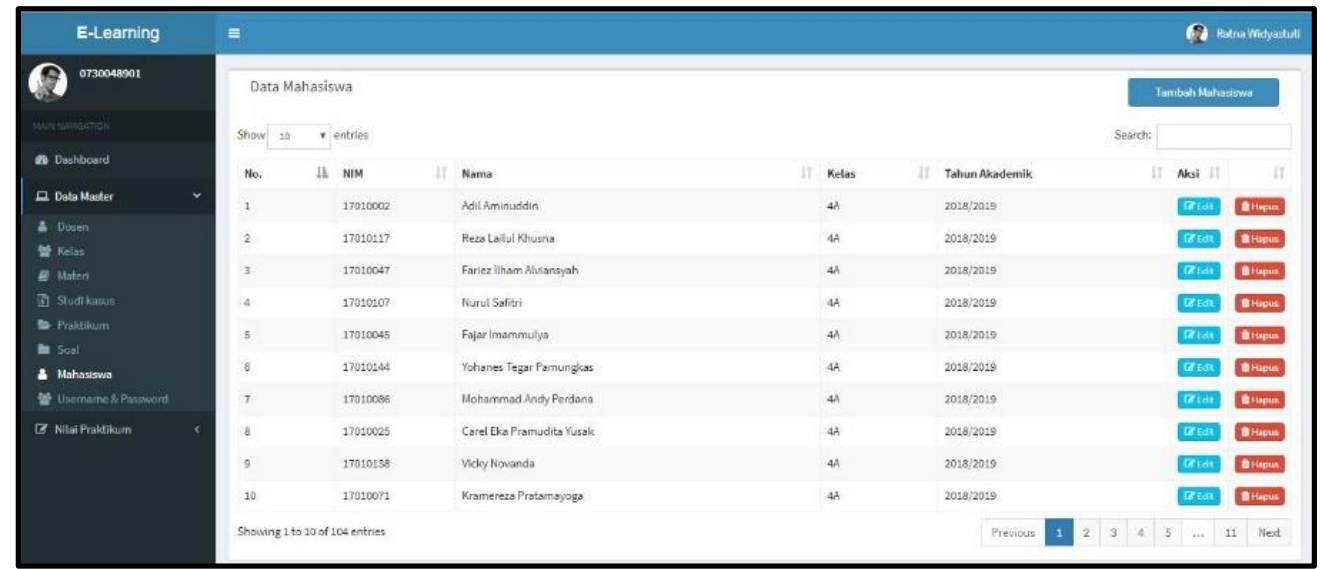

Gambar 16. Halaman Tampil Data Mahasiswa

\section{Halaman Username dan Password}

Halaman Master Username \& Password menampilkan data username-password admin dan mahasiswa seperti ditunjukkan Gambar 17. Data tersebut yang ditampilkan yaitu username, password, level serta aksi edit dan hapus. Halaman ini juga terdapat button tambah administrator untuk 
menambahkan dosen sebagai administrator. Button generate user mahasiswa untuk menambahkan user mahasiswa.

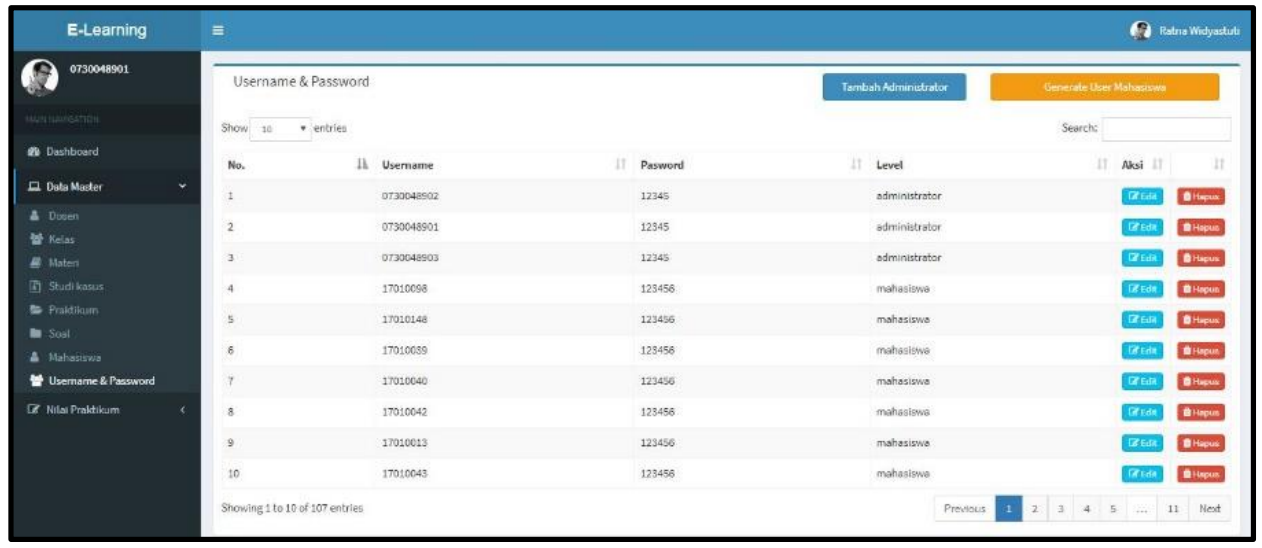

Gambar 17. Halaman Username dan Password

\section{Halaman Data Master Nilai Praktikum}

Halaman Data master Nilai Praktikum menampilkan nilai mahasiswa dikelompokkan berdasarkan kelas, ditunjukkan pada Gambar 18. Data yang ditampilkan yaitu NIM, nama, dan detail. Aksi detail akan menampilkan detail dari setiap mahasiwa antara lain nama praktikum, nilai praktikum, rata-rata.

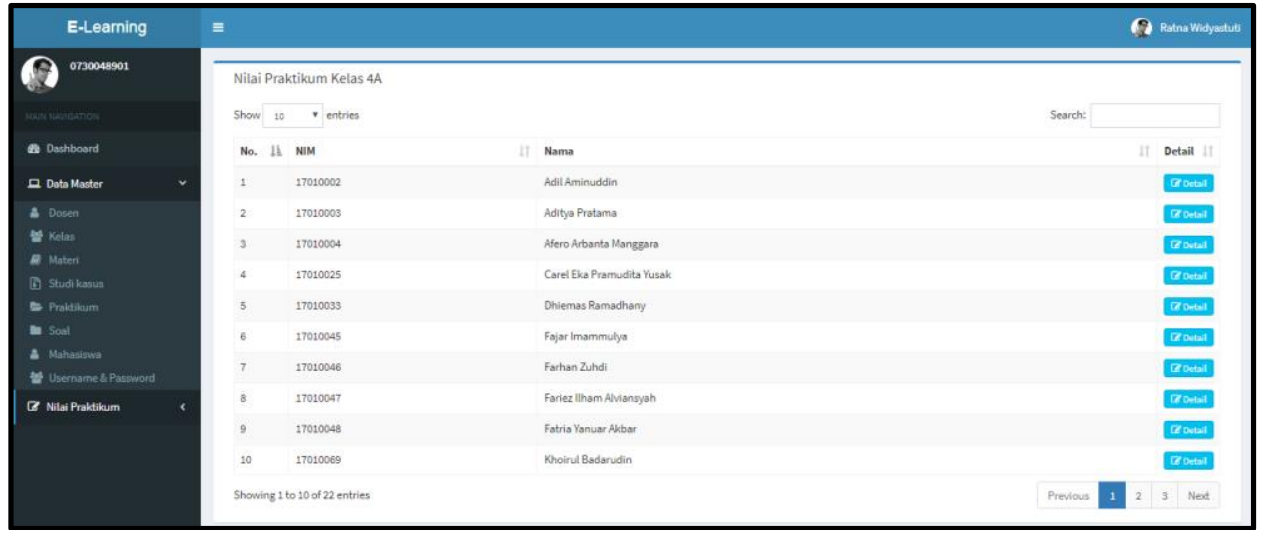

Gambar 18. Halaman Tampil Data Nilai

\section{Halaman Mahasiswa}

Pada menu Materi terdapat delapan materi yang terdiri dari Bab 1 Halaman Kerja SPSS, Bab 2 Uji Hipotesis, Bab 3 Uji Normalitas Data, Bab 4 Uji Statistika Parametrik, Bab 5 Uji Anava, Bab 6 Uji Statistika Non Parametrik, Bab 7 Uji Korelasi, Bab 8 Uji Regresi. Seperti ditunjukkan pada Gambar 19. 


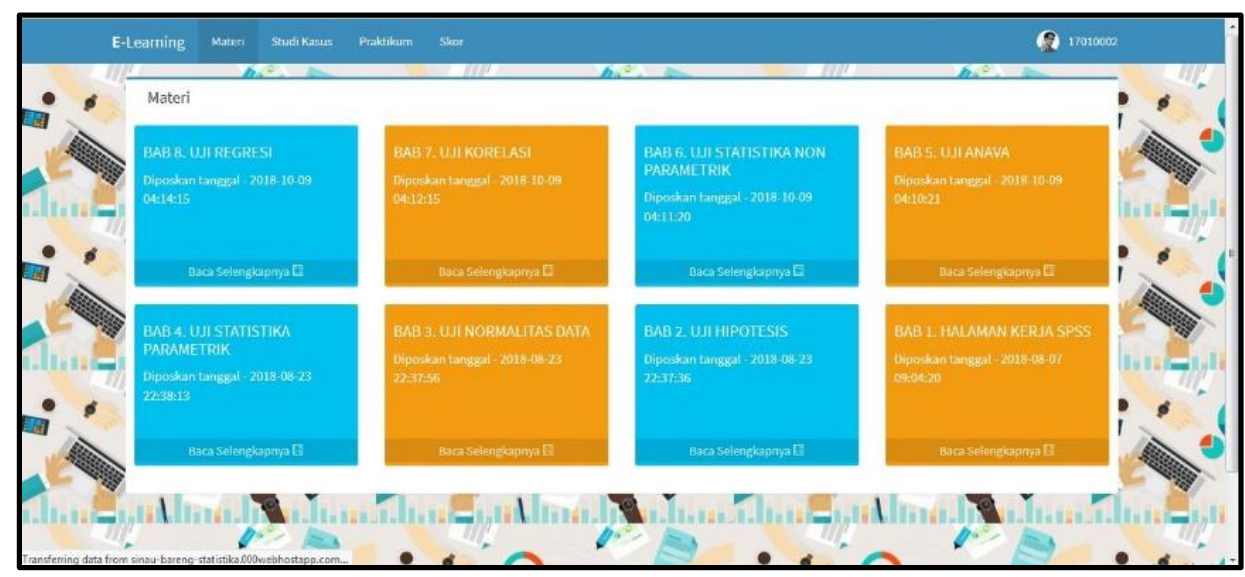

Gambar 19. Halaman Materi

Terdapat contoh tampilan dari isi materi setiap bab, yang mana mahasiswa dapat mengambil materi tersebut dengan cara klik tombol unduh materi.Seperti ditunjukkan pada Gambar 20.

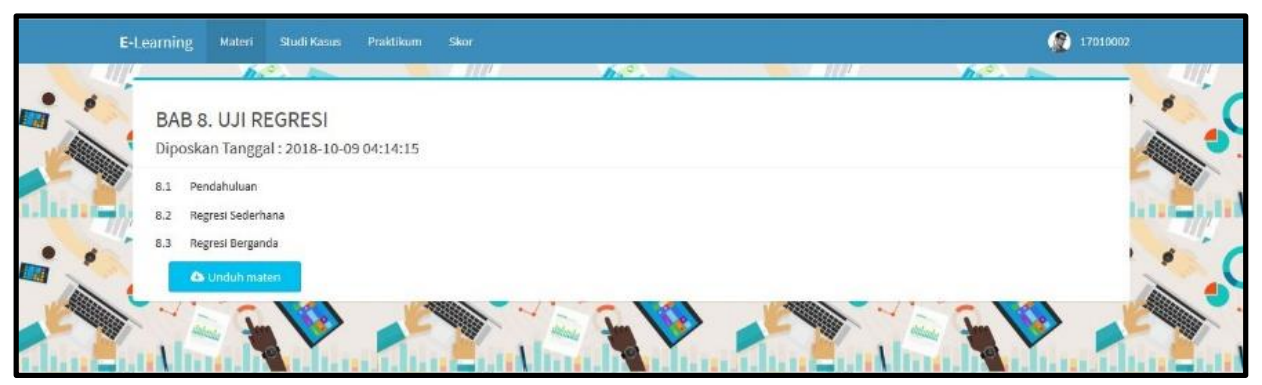

Gambar 20. Halaman Materi per Bab

Menu Praktikum menampilkan halaman praktikum yang berisi soal-soal praktikum yang mana mahasiswa dapat mengerjakan soal-soal dari praktikum ini yang bertujuan menguji mahasiswa sejauh mana mahasiswa memahami setiap materi. Seperti ditunjukkan pada Gambar 21.

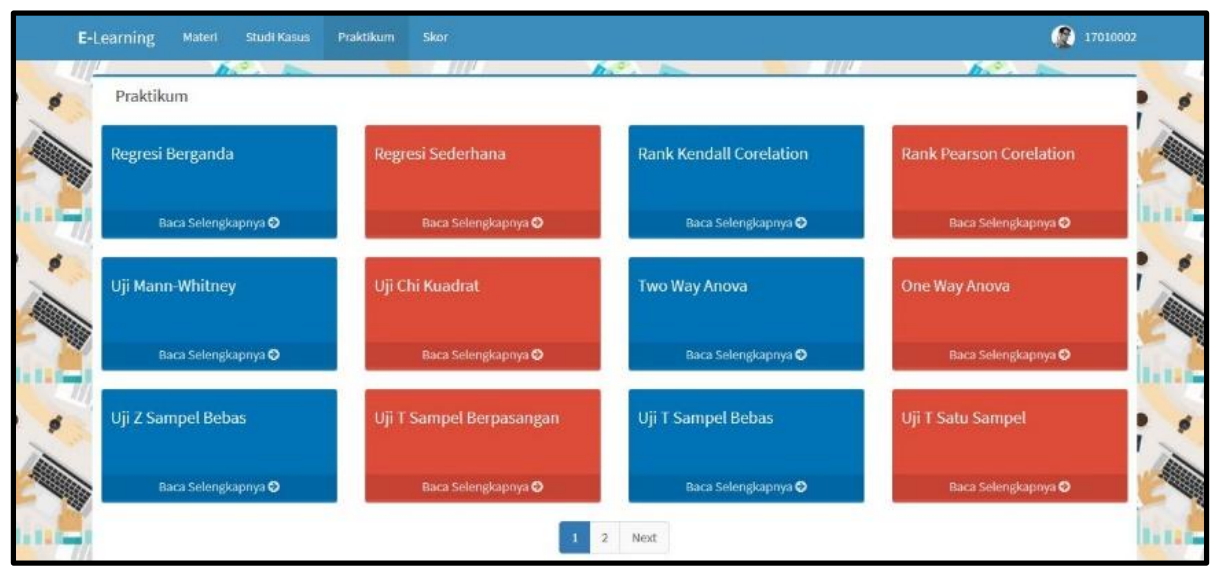

Gambar 21. Halaman Praktikum

Menu studi kasus menampilkan halaman studi kasus yang berisi soal dari setiap materi dan tutorial pengerjaan menggunakan SPSS. Seperti ditunjukkan pada Gambar 22. 


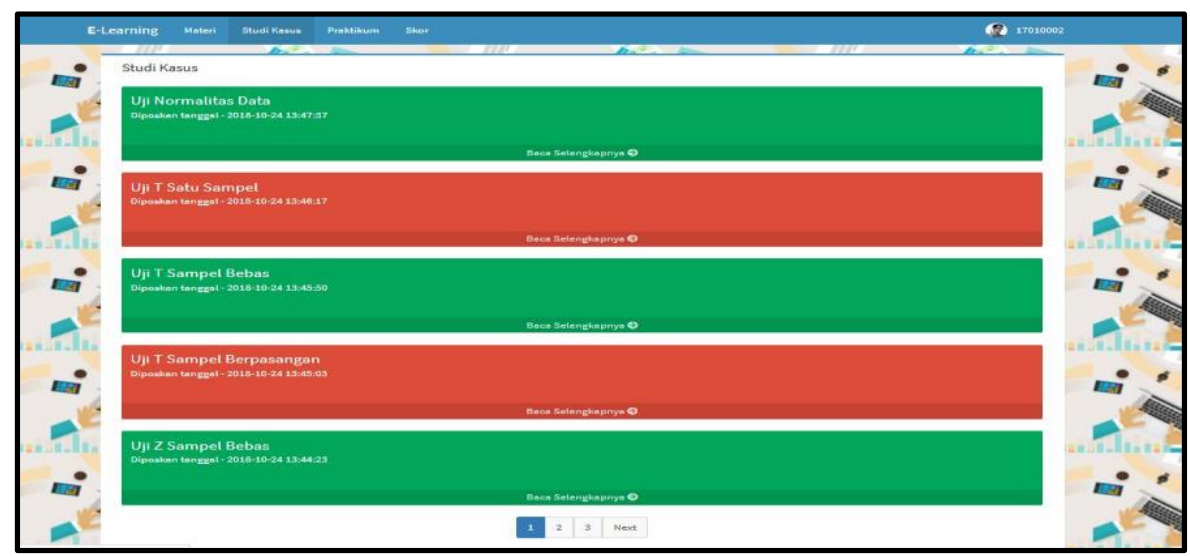

Gambar 22. Halaman Studi Kasus

Menu Skor menampilkan halaman skor yang berisi rincian nilai praktikum yang telat di kerjakan setiap mahasiswa. Seperti ditunjukkan pada Gambar 23.

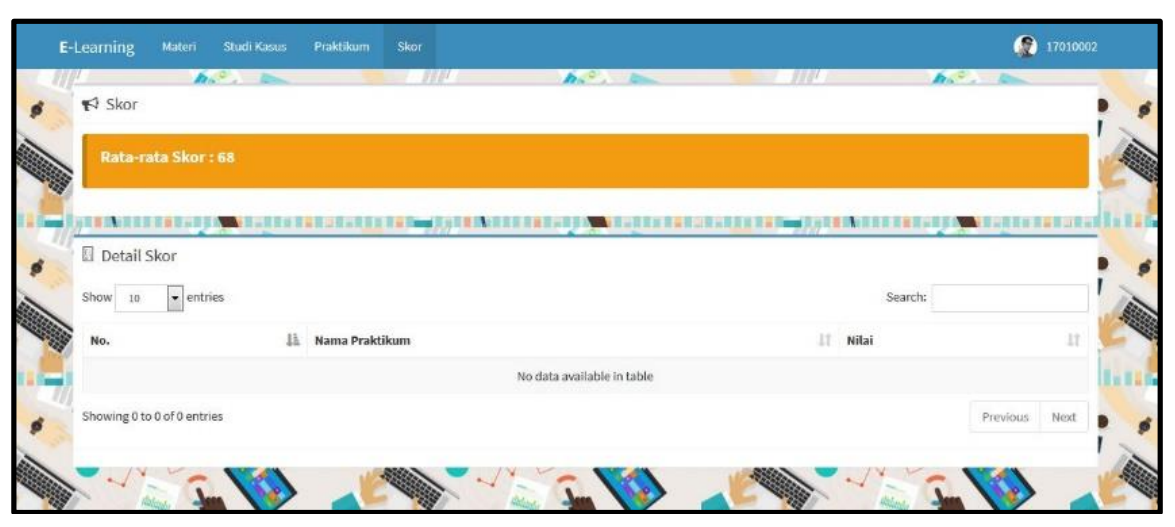

Gambar 23. Halaman Skor

Modul praktikum SPPS 20 Berbasis Web yang telah kembangkan pada tahap pengembangan selanjutnya dilakukan tahap penilaian. Tahap penilaian produk terdiri atas penilaian kevalidan, keefektifan dan kepraktisan. Padatahap ini dilakukan dua aktivitas,yaitu (a) validasi ahli dan praktisi untuk menilai kevalidan, (b)uji coba produk yang meliputi uji coba kelompok kecil. Validator ahli terdiri dari 2 (dua) orang dosen program studi Teknik Informatika Politeknik Kediri pengampu matakuliah desain web dan Rekayasa Perangkat Lunak (RPL). Selain itu modul praktikum berbasis web juga diuji cobakan pada 2 (dua) orang dosen program studi Pendidikan Matematika yang merupakan pengajar matakuliah statistika 1. Adapun hasil validasi ahli dan praktisi ditunjukkan pada Tabel 3.

Tabel 3 Hasil Kuesioner Validitas Media

\begin{tabular}{|c|c|c|c|c|c|}
\hline \multirow[t]{2}{*}{ No } & \multirow[t]{2}{*}{ Indikator } & \multicolumn{4}{|c|}{ Skor Validator ke- } \\
\hline & & 1 & 2 & 3 & 4 \\
\hline 1 & $\begin{array}{l}\text { Petunjuk penggunaan atau informasi di web bersifat } \\
\text { komunikatif dan mudah dimengerti }\end{array}$ & 3 & 3 & 4 & 4 \\
\hline 2 & Menu atau fitur pada web mudah digunakan & 3 & 3 & 4 & 3 \\
\hline 3 & Secara grafis web nyaman digunakan & 3 & 3 & 4 & 4 \\
\hline 4 & Tulisan yang digunakan pada web mudah dibaca & 3 & 3 & 4 & 4 \\
\hline 5 & Modul berbasis web sesuai kebutuhan & 3 & 3 & 4 & 4 \\
\hline 6 & $\begin{array}{l}\text { Modul berbasis web mempunyai kemampuan dan fungsi } \\
\text { sesuai yang diharapkan }\end{array}$ & 3 & 3 & 4 & 3 \\
\hline & Skor Total Masing-masing Validator & 18 & 18 & 24 & 22 \\
\hline
\end{tabular}


Skor Total Keempat Validator $(S T) \quad 82$

Persentase Skor Total (SV) $\quad 85,42 \%$

Berdasarkan hasil validasi sistem dari 2 (dua) validator dan 2 (dua) praktisi diperoleh skor total (SV) sebesar $85,42 \%$. Menurut kriteria kevalidan, maka sistem dapat dikatakan valid.Adapun hasilujicobaModul praktikum SPPS 20 Berbasis Web ditunjukkan pada Tabel 4.

Tabel 4 Hasil Kuesioner Uji Coba Mahasiswa

\begin{tabular}{|c|c|c|c|c|c|c|c|c|c|c|c|c|}
\hline \multirow{2}{*}{ No } & \multirow{2}{*}{ Responden } & \multirow{2}{*}{$\begin{array}{c}\text { Jenis } \\
\text { Kelamin }\end{array}$} & \multicolumn{9}{|c|}{ Pertanyaan ke- } & \multirow{2}{*}{ Rata-rata } \\
\hline & & & 1 & 2 & 3 & 4 & 5 & 6 & 7 & 8 & 9 & \\
\hline 1 & $\mathrm{~S} 1$ & Laki-laki & 4 & 3 & 4 & 4 & 4 & 3 & 4 & 2 & 3 & 3.44 \\
\hline 2 & $\mathrm{~S} 2$ & Laki-laki & 2 & 4 & 2 & 4 & 4 & 3 & - & 5 & 4 & 3.11 \\
\hline 3 & S3 & Laki-laki & 5 & 4 & 4 & 4 & 5 & 4 & 4 & 4 & 5 & 4.33 \\
\hline 4 & $\mathrm{~S} 4$ & Laki-laki & 4 & 4 & 3 & 4 & 4 & 3 & 5 & 3 & 4 & 3.78 \\
\hline 5 & S5 & Laki-laki & 4 & 4 & 3 & 4 & 3 & 3 & 4 & 4 & 4 & 3.67 \\
\hline 6 & S6 & Laki-laki & 4 & 4 & 4 & 3 & 4 & 4 & 4 & 4 & 3 & 3.78 \\
\hline 7 & S7 & Perempuan & 4 & 4 & 4 & 4 & 4 & 4 & 5 & 4 & 3 & 4.00 \\
\hline 8 & S8 & Laki-laki & 3 & 4 & 4 & 4 & 3 & 4 & 4 & 4 & 4 & 3.78 \\
\hline 9 & S9 & Laki-laki & 4 & 4 & 3 & 4 & 4 & 4 & 4 & 4 & 4 & 3.89 \\
\hline 10 & S10 & Laki-laki & 4 & 4 & 4 & 4 & 5 & 5 & 4 & 4 & 4 & 4.22 \\
\hline 11 & $\mathrm{~S} 11$ & Perempuan & 4 & 4 & 3 & 4 & 4 & 4 & 4 & 4 & 4 & 3.89 \\
\hline 12 & S12 & Laki-laki & 2 & 5 & 5 & 5 & 4 & 4 & 4 & 4 & 4 & 4.11 \\
\hline 13 & $\mathrm{~S} 13$ & Perempuan & 3 & 4 & 5 & 5 & 4 & 3 & 5 & 4 & 4 & 4.11 \\
\hline & & & 3.62 & 4.00 & 3.69 & 4.08 & 4.00 & 3.69 & 3.92 & 3.85 & 3.85 & 3.85 \\
\hline
\end{tabular}

Berdasarkan perhitungan nilai kuesioner ujicoba yang diisikan oleh mahasiswa dan sejawat diperoleh kesimpulan bahwa rata-rata yang diperoleh sebesar 3,85, dengan saran-saran perbaikan yang diberikan. Sesuai kriteria rata-rata nilai 3,85 tersebut menyatakan bahwa respon pengguna sangat baik.

\section{Kesimpulan dan Saran}

Penelitian dengan judul Modul praktikum SPSS versi 20 berbasis web telah selesai dibuat dan dibahas, kesimpulan dari penelitian ini sebagai berikut. Melalui modul berbasis web dosen dan mahasiswa dapat mengelola perkuliahan praktikum SPSS secara online yang dapat diakses melalui internet secara umum. Alamat untuk mengakses sistem tersebut adalah http://sinau-barengstatistika.000webhostapp.com. Modul praktikum SPSS versi 20 berbasis web yang dibuat memenuhi kriteria valid ditunjukkan dari hasil angket validitas sebesar $85,42 \%$. Respon mahasiswa terhadap implementasi modul praktikum SPSS versi 20 berbasis web juga sangat baik terlihat dari hasil angket penialai kriteria sangat baik ditunjukkan dari hasil angket respon menunjukkan hasil sebesar 3,85.

Berdasarkan kesimpulan dan pembahasan hasil penelitian maka dikemukakan beberapa saran sebagai berikut :

1. Untuk memasyarakatkan sistem perkuliahan menggunakan modul berbasis web baik sebagai salah satu model pembelajaran maupun sebagai pendukung tatap muka, perlu dilakukan terlebih dahulu sosialisasi e-learning kepada dosen dan mahasiswa.

2. Pembelajaran mata kuliah statistika dan probabilistic dengan memanfaatkan modul praktikum SPSS versi 20 dapat digunakan sebagai acuan dalam memantau perkembangan mahasiswa lama proses pembelajaran mengenai SPSS. 


\section{DAFTAR PUSTAKA}

Anwar, M. (2010). Pengembangan Media Pembelajaran Berbasis Teknologi Informasi. Jurnal Pendidikan Akuntansi Indonesia, Vol. 8 No. 2 Hal. 1-10.

Barokati, N., \& Annas, F. ( 2013 ). Pengembangan Pembelajaran Berbasis Blended Learning pada Mata Kuliah Pemrograman Komputer (Studi Kasus: Unisda Lamongan). Jurnal Sistem Informasi Volume 4 Nomor 5, 352-359.

Hobri. (2010). Metodologi Pengembangan Aplikasi pada Penelitian Pendidikan Matematika. Jember: Pena Salsabila.

Lasmiyati, \& Harta, I. (2014). Pengembangan Modul Pembelajaran untuk Meningkatkan Pemahaman Konsep dan Minat Siswa SMP. Pythagoras: Jurnal Pendidikan Matematika., Vol. 9 No.2, Hal. 161-174.

Rusman. (2017). Belajar dan Pembelajaran berorientasi Standar Proses Pendidikan. Jakarta: Kencana.

Sadiman, A. S., Raharjo, \& dkk. (2006). Media Pendidikan. Jakarta: Rajawali Press.

Tirta, I. M. (2014). Pengembangan E-Modul Statistika Terintegrasi dan Dinamik dengan R-Shiny dan MathJax. Prosiding Seminar Nasional Universitas Negeri Jember, 19 November 2014. Jember: Universitas Negeri Jember. 